This item was submitted to Loughborough's Research Repository by the author.

Items in Figshare are protected by copyright, with all rights reserved, unless otherwise indicated.

\title{
Knowledge management activities and strategic planning capability development
}

PLEASE CITE THE PUBLISHED VERSION

https://doi.org/10.1108/EBR-03-2019-0034

PUBLISHER

Emerald Publishing Limited

VERSION

AM (Accepted Manuscript)

\section{PUBLISHER STATEMENT}

This paper was accepted for publication in the journal European Business Review and the definitive published version is available at https://doi.org/10.1108/EBR-03-2019-0034.

LICENCE

CC BY-NC 4.0

\section{REPOSITORY RECORD}

Hughes, Paul, and lan Hodgkinson. 2020. "Knowledge Management Activities and Strategic Planning Capability Development”. Loughborough University. https://hdl.handle.net/2134/9980576.v1. 


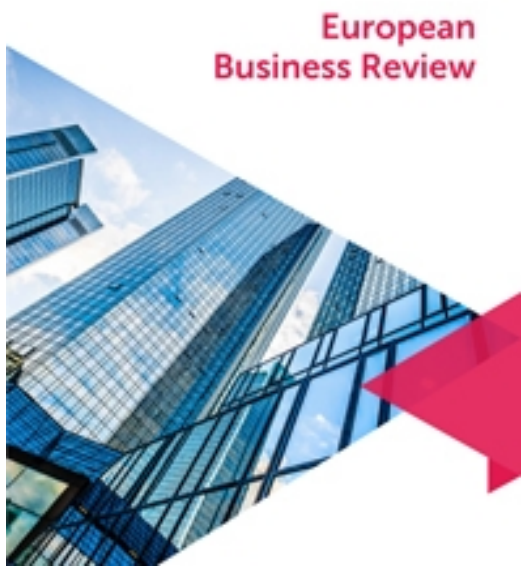

Knowledge Management Activities and Strategic Planning Capability Development

\begin{tabular}{|r|l|}
\hline Journal: & European Business Review \\
\hline Manuscript ID & EBR-03-2019-0034.R2 \\
\hline Manuscript Type: & Article \\
\hline Keywords: & $\begin{array}{l}\text { Knowledge-based theory, Strategic planning, Planning capability, } \\
\text { Decision-making, Knowledge management }\end{array}$ \\
\hline \multicolumn{2}{|l}{} \\
\hline
\end{tabular}

\section{SCHOLARONE ${ }^{\text {m }}$ \\ Manuscripts}




\title{
Knowledge Management Activities and Strategic Planning Capability Development
}

\begin{abstract}
Purpose - While the strategic management literature extols the virtues of engaging in strategic planning for superior performance, how a dynamic strategic planning capability can be developed remains underexplored; a knowledge void addressed by the paper through applying knowledge-based theory.

Design/methodology/approach - A mail survey was sent to high technology firms randomly sampled from the Kompass Directory of UK businesses. Firms were sampled at the SBU level, given the focus on strategic planning capability.

Findings - An organization's strategic planning capability derives from extensive information distribution and organizational memory. While learning values is non-significant, symbolic information use degrades the development of a strategic planning capability.

Research implications - By investigating the contributory activities that lead to strategic planning capability development, the findings establish how strategic planning materializes in organizations. Further, the differential effects found for knowledge management activities on strategic planning capability development extends empirical studies that suggest knowledge is always a central tenet of strategic planning.

Practical implications - A set of key knowledge activities are identified that managers must address for strategic planning capability development: strategic planning routines and values of search, analysis, and assessment should be appropriately informed by investments in knowledge dissemination and memory on a continual basis. Meanwhile, information misuse compromises strategic planning capabilities and managers must protect against out-of-context or manipulated information from infiltrating into organizational memory.

Originality/value - Despite the advent of the Knowledge-Based Theory and its core premise that capabilities derive from knowledge management activities, little research has been conducted into demonstrating the knowledge-based antecedents of a strategic planning capability.
\end{abstract}

Keywords Knowledge-based theory, Knowledge management, Strategic planning, Planning capability, Decision-making.

Paper Type Research Paper 


\section{Introduction}

The strategy literature extols the virtues of engaging in strategic planning, which remains one of the most commonly used tools in business practice (Thomas and Ambrosini, 2015). This has led studies of planning to concentrate on its performance consequences without due consideration to its development (Hughes et al., 2018; Sarkar and Osiyevskyy, 2017). Consequently, the theoretical and conceptual development of strategic planning has been 'left behind' in the strategic management literature (Wolf and Floyd, 2017), limiting knowledge on how strategy materializes in organizations (Dameron et al., 2015; Thomas and Ambrosini, 2015). More recently, however, strategic planning has been conceptualized and empirically validated as an essential capability for success (Hughes et al., 2019). Such developments raise an important strategic dilemma: how can organizations develop a strategic planning capability?

Past research into strategic planning has identified a number of antecedents to it across different theoretical perspectives. For example: Fredrickson (1984) identifies centralization, formalization, and complexity as structural antecedents to strategic planning (decision processes) while Hart and Banbury (1994) posit that strategic planning capabilities can evolve through purposeful design; Menon et al. (1999) expand on both and introduce innovative culture as antecedents to strategy-making; Grant (2003) discusses externalities (e.g., changing environmental conditions; varying reference points) as foundations; Atuahene-Gima and Murray (2004) view process rewards, conflict, and extra-industry relationships as antecedents to comprehensive strategic planning; Whittington et al. (2011) find societal, cultural, technological, and organizational factors that influence strategic planning; Thomas and Ambrosini (2015) provide guidance as to how formal and informal controls are salient antecedents to materializing strategy through comprehensive strategic planning; while Hughes et al. (2018) identify cognitive 
(managerial reasoning) antecedents to strategic planning. In this paper, the development of the strategic planning capability through the knowledge-based theory (KBT) is examined.

How organizations build on and apply knowledge is an important topic to pursue in the examination of capability development (Marsh and Stock, 2006). There is agreement in the dynamic capabilities literature that knowledge management - the creation, deployment, and storage of knowledge (Grant, 1996a) — facilitates capability development (Friesl, 2012; Grant, 1996a; Marsh and Stock, 2006; Teece, 2014). For instance, new knowledge, existing knowledge stocks and management team learning have been observed to shape firms' strategic goals and actions in pursuit of these goals (Crick and Crick, 2014). Similarly, through the knowledge-based activities of creating, deploying and storing knowledge, it would be expected that a strategic planning capability can be developed. This study thus examines a set of knowledge activities that may impact strategic planning capability development: information distribution, learning values, organizational memory, and symbolic information use.

A knowledge-based perspective on the antecedents to a dynamic strategic planning capability is adopted as an appropriate theoretical lens as strategic planning is typically seen in terms of reliance on systematic analysis, evaluation, strategic option creation, and purposeful reliance on information for comprehensiveness in the aforementioned elements of the strategic planning process (e.g., Menon et al., 1999; Bailey et al., 2000). These elements, then, would seem to rely on knowledge as the building blocks for success in strategic planning. What is relatively absent, still, for both practitioners and scholars, is an understanding of the knowledgebased antecedents to strategic planning beyond normative assumptions that there must be significant effects given the previous assumptions regarding the nature of the strategic planning process. Two contributions to the strategic management and planning literatures are offered. 
First, by investigating the contributory activities that lead to strategic planning capability development, new insight on how planning and strategy materializes in organizations is presented (Thomas and Ambrosini, 2015). Second, building on our first contribution and drawing on the KBT, the findings reveal different effects on strategic planning capability by knowledge management activities and in so doing extend empirical studies that suggest knowledge is always a central tenet of strategic planning (e.g., Atuahene-Gima and Li, 2004; Atuahene-Gima and Murray, 2004; Rogers et al., 1999; Teece, 2014). Collectively, addressing the antecedents of strategic planning capability from a KBT lens addresses the lack of wider theory integration to advance theoretical and empirical knowledge on contemporary strategic planning; as called for by Dameron et al. (2015), Hughes et al. (2018), Whittington et al. (2016), and Wolf and Floyd (2017).

\section{A Dynamic Strategic Planning Capability}

Consideration of planning as a capability has been evidenced in the literature through investigation of marketing planning capability (Slotegraaf and Dickson, 2004), product portfolio planning capability (Newey and Zahra, 2009), and more broadly, strategic decision-making as capability (Hughes and Morgan, 2007; Hughes et al., 2019). Fundamental to the strategy process, planning "can cultivate an organizational capability through the integration, combination, and reconfiguration of a firm's resources" (Slotegraaf and Dickson, 2004, p. 371). The description of planning offered by Bailey et al. (2000, p. 153) clearly aligns to Teece's (2014, p. 332) description of dynamic capabilities as allowing "management to develop conjectures about the evolution of consumer preferences, business problems, and technology; validate and fine-tune them; and then act on them". Specifically, planning is an: 
"intentional process involving a logical, sequential, analytic and deliberate set of procedures.

The organization and its environment are systematically analyzed. Strategic options are generated and systematically evaluated. Based on this assessment, the option is chosen that is judged to maximize the value of outcomes in relation to organizational goals."

It is a rational, analytical decision-making ability enabling the firm to transform proactively to environmental change, which distinguishes strategic planning from functional planning (i.e., at operational, project, or product levels). Strategic planning as dynamic capability should not be thought of as simply the development of a strategic plan (MacLean and MacIntosh, 2015) but as an activity that continually integrates, combines, and reconfigures the resource base (Slotegraaf and Dickson, 2004). The overall purpose is to achieve congruence with customer needs and market opportunities and reduce the risk of environmental uncertainty (Crick and Crick, 2014). More specifically, by selecting appropriate strategic options based on continual objective internal and external analyses (Wolf and Floyd, 2017), firms with a strategic planning capability can anticipate and respond to changing environmental conditions. This refutes the notion that strategic planning is for predictable environments only.

A dynamic strategic planning capability, thus, requires the organization to integrate and apply knowledge continually in their planning processes (Grant, 1996a). Yet, recent examinations of strategic planning (e.g., Atuahene-Gima and Li, 2004; Slater et al., 2006; Slotegraaf and Dickson, 2004; Thomas and Ambrosini, 2015; Wolf and Floyd, 2017) have neglected its origins, with scholarly attention narrowly focused on the relationship between strategic planning and organizational performance (Sarkar and Osiyevskyy, 2017; Wolf and Floyd, 2017). Strategic planning is an information and knowledge intensive capability and the quality of planning decisions is reliant upon knowledge (Grant, 1996a). Therefore, knowledge management is widely considered a central tenet of strategic planning (Atuahene-Gima and Li, 
2004; Rogers et al., 1999). Yet, while knowledge-based insights on the development of capabilities have been garnered (Dimitriades, 2005; Marsh and Stock, 2006), the role of different knowledge management activities as precursors to the development of a dynamic strategic planning capability requires investigation.

\section{Strategic Planning and Knowledge Antecedents}

Organizations are systems that scan and acquire information from their environments, distribute, and interpret that information, and then store the information gained in organizational memory (Huber, 1991). Organizations adept at environmental scanning and knowledge management can develop stronger dynamic strategic planning capabilities to sense, seize, and reconfigure in their strategizing (Teece, 2014). Consequently, they are able to allocate and reallocate resources effectively to the most appropriate strategy at any point in time (Grant, 1996b). Within KBT, organizations are viewed as entities that create, store, and deploy knowledge (Grant, 1996a). The KBT is drawn on to conceptualize knowledge management as comprising the activities of information distribution, learning values, memory, and symbolic information use.

Information distribution, learning values, and memory are knowledge resources that are heterogeneous and imperfectly mobile between firms (Hughes and Morgan, 2007). Hence, there will be variation in the degree to which different organizations invest in different learning or knowledge activities (Zollo and Winter, 2002). The knowledge management activities examined are suggested to play a prominent role in directing firm decision-making, proactively enabling firm's generative learning for the execution of fundamental strategic shifts; with the intent to create or maintain advantage (e.g. Baker and Sinkula, 1999). 
Research into organizational learning, including insights from the KBT, focuses on the acquisition and creation of organizational knowledge (Grant, 1996a) that have the potential to direct behavior (Slater and Narver, 1995). The desire to do so is manifest in the value a firm puts on the importance of learning (Baker and Sinkula, 1999). However, an organization may be adept at knowledge acquisition but unable to apply that knowledge through their strategic planning processes; hence, if organizations can be deemed to be entities that create knowledge de facto, the challenge is to disseminate this knowledge and store this knowledge effectively for decision-making. Indeed, forgetting knowledge is itself an example of a failure in knowledge acquisition (Casey and Olivero, 2011). For instance, exploiting stored information from an organization's history to inform present decisions (Walsh and Ungson, 1991) is an example of memory driving decision-making.

Rather than examining knowledge management activities through a process lens, then, the concern of this study is the content of those activities. This focus enables an examination of the ability of firms to apply knowledge management activities in pursuit of competitive advantage (Baker and Sinkula, 1999; Grant, 1996a). Information dissemination, learning values, and memory represent knowledge resources available to the firm, much in the same way that learning has been extensively treated as a firm resource in extant literature (Hunt, 2000; Hughes and Morgan, 2007, 2008; Hunt and Morgan, 1995; Nahapiet and Ghoshal, 1998). Thus, when exploited effectively to drive strategic planning processes, firms will achieve an advantage over competitors and conversely, “...those weaker at learning are expected to suffer in developing value and in reaching desired product-market goals as a result” (Hughes and Morgan, 2007, p. 508). An extension of this inability to use knowledge resources effectively is when knowledge is used irresponsibly in planning processes. Such symbolic information use is typically neglected in 
decision-making investigations, despite the many contemporary examples of 'fake news' and 'data fiction' feeding into decision practices. How the set of knowledge management activities impact firms' ability to develop a strategic planning capability is now investigated.

\section{Hypotheses Development: Knowledge Management Activities}

Distributing information organization-wide is fundamental to knowledge sharing that is necessary for effective strategic planning. Following the KBT, without distribution of knowledge, knowledge assets remain resident within individual employees and cannot be readily codified and transferred for the development of a strategic planning capability (Grant, 1996a; Teece, 2014). Widespread information distribution can, therefore, contribute to successful strategy development by drawing on collective intelligence. With greater quality and quantity of information, decision-makers can then respond effectively. To develop a strategic planning capability, the necessary decision-makers involved in formulating strategy, searching for solutions to strategic problems, assessing alternatives, evaluating potential strategic options, and systematic analysis of the business environment (e.g., Bailey et al., 2000), require information as swiftly as possible (Rogers et al., 1999); this cannot happen if information is not distributed. Hypothesis 1. Strategic planning capability is positively influenced by information distribution.

Learning values ensure that organizations have procedures in place so that learning is accomplished as efficiently as possible (Brews and Hunt, 1999); evidenced by a focus on learning as an investment and valuing learning as key to improvement (Morgan and Turnell, 2003). This conceptualization is consistent with the work of Baker and Sinkula (1999), and specifically, their depiction of the second-order construct learning orientation; defined as an 
organizational characteristic that "reflects the value that a firm places not only on adroitly responding to changes in the environment but on constantly challenging the assumptions that frame the organization's relationship with the environment" (Baker and Sinkula, 1999, p. 412 [emphasis added]). Thus, the degree of strategic planning is expected to be a function of a firm's focus or emphasis on learning (Sinkula, 1994); as has been observed in the development of portfolio planning capabilities (Newey and Zahra, 2009).

Commitment to learn is a key feature of a learning orientation and highlights the necessity of instilling learning values as central to firm action (Baker and Sinkula, 1999). Learning values that stress the importance of knowledge about customers and the market arena should, in turn, encourage the development of planning processes (e.g., Crick and Crick, 2014; Newey and Zahra, 2009). The presence of learning values enables "firms to regularly detect and correct errors in theory in use. If an organization places little value on learning, little learning is likely to occur" (Baker and Sinkula, 1999, p. 413). Thus, if strategic planning is constructed from a collection of routines, which are behaviors that are learned, highly patterned, repetitious (or quasi-repetitious), and based in part in tacit knowledge, learning values are central (Slotegraaf and Dickson, 2004). This logic is depicted in Teece's (2014) conceptualization of process 'signatures', that "arise from a company's heritage, including its prior management actions, certain irreversible investments, and context-specific learning” (Teece, 2014, p. 334). Conversely, too great a focus on learning may be harmful due to cost, time, and bounded rationality. Nevertheless, it is likely that learning values will aid the development of a strategic planning capability by enabling the resource base to be reconfigured and thereby mitigating the potential for routine rigidity and inertia (cf. Mintzberg, 1994). Therefore:

Hypothesis 2. Strategic planning capability is positively influenced by learning values. 
Symbolic information use extends from the cognitive biases of managers, which have being identified as a source of vulnerability that can negatively influence the effectiveness of planning systems (Wolf and Floyd, 2017). By focusing attention on people and what they do in the strategy process (MacLean and MacIntosh, 2015), it is evident that information can be deliberately misused or taken out of context during strategic planning (Menon and Varadarajan, 1992). The organizational processes through which individuals engage in knowledge deployment may be obscured (Grant, 1996a) through symbolic information use. This refers to the collection and misuse of information to validate beliefs or past decisions (Diamantopoulos and Souchon, 1999), or the "distortion and manipulation of information to support, legitimize, and sustain the opinion or dispositions of a strategic decision-maker" (Hughes et al., 2010, p. 613). This encompasses current information collection activities that may be used out-of-context and manipulated to suit the agenda of the person(s) using the information.

This is likely to negatively affect strategic planning capability for two reasons. First, information misused or manipulated from its original context could deliver a seemingly correct or advantageous strategic solution to managers. However, this strategy is unlikely to be optimal given that it is the consequence of biased thinking and flawed judgments, thus clouding sensing, seizing, and reconfiguring ability e.g., it would likely not facilitate a strong response to the market or enable resources to be allocated effectively. As such, a strategic planning capability will not develop as the ability to plan is undermined. Second, information used to support the opinions or desires of managers could be in conflict to the firm's competitive truth. The quality of the strategic planning process deteriorates as the amount of biased or misused information 
increases and this undermines the planning effort; subsequently, managers may decrease the extent of strategic planning, thus, eroding their strategic planning capability.

Hypothesis 3. Strategic planning capability is negatively influenced by symbolic information use.

Organizational memory is a repository of collective organizational insights (Day, 1994) for future use (Sinkula, 1994) in the development of capabilities (e.g., Marsh and Stock, 2006). The presence of prior related knowledge or 'knowledge signatures', is important to the development of capabilities (Teece, 2014) and provides existing knowledge stocks that are accessible for strategic planning purposes. Critics of strategic planning often comment on its time-consuming and costly nature (Mintzberg, 1994). But, such perceived lead times to strategic planning processes may be shortened by relying on memory for reducing the costs of 'search' associated with problem-solving activities (Marsh and Stock, 2006), which are experienced during strategic planning (Bailey et al., 2000). Many organizations develop habitual ways of interpreting events (Hodgkinson et al., 2014) and miss the significance of new knowledge necessary for strategic planning, but utilizing prior related knowledge can enable managers to recognize the value of new information for capability development (Marsh and Stock, 2006). Under the KBT, the absorption and interpretation of knowledge in this way is integral to an organization's ability “to define problems and to generate, to evaluate, and to choose alternatives" (Marsh and Stock, 2006, p. 425); consistent with the characteristics of a strategic planning capability. Managers can then retrieve information on customers, the environment, competitors, and technology to hasten strategic planning and lessen the perceived cost and time of developing planning capabilities. Thus: 
Hypothesis 4. Strategic planning capability is positively influenced by organizational memory.

\section{Research Methods}

A mail survey was sent to a thousand high technology firms randomly sampled from the Kompass Directory of UK businesses. Key informants are Senior Executives as they are most likely to have specific knowledge on strategic planning, knowledge management, and are justifiably expected to provide reliable information. Firms were sampled at the SBU level. Sampled firms were required to be in business for longer than five years and employ a minimum of 100 full-time employees as a means to control for size and age in the research design. High technology firms are focused on given their salience to the KBT. They experience greater environmental uncertainty and dynamism and, thus, are an appropriate setting to examine strategic planning capability development.

Responses were received from 202 firms with 126 being eligible, consistent with past planning research (Slotegraaf and Dickson, 2004). To increase the response rate a random sample of 150 non-respondents were telephoned and invited to participate in the study or ascertain reasons for non-response. Reasons given included 'no interest in the study', 'no time', 'company policy not to respond to surveys', and so forth. Of these contacted non-respondents, 13 firms responded by completing the survey. Analysis of variance between these respondents and initial respondents reveal no significant statistical difference between them on all model constructs. The final number of responses totaled 139 firms. Second, examination of a random sample of 50 non-respondents and 50 respondents on both profit data and firm size reveal no significant difference between the two groups. Respondent firms have on average US\$144 million sales turnover in the last 12 months; in business for an average of 52 years; and, 
competing in their current product-market for on average 44 years. Respondents are mostly Chief Executives (58\%) with the remainder being Directors (25\%) or Senior Managers (17\%). Respondents average 22 years of working experience and tenures of 11 years. Respondents' belief regarding response accuracy averaged 5.61 on a 7-point scale.

\section{Measures}

Measures were adapted from existing batteries in the strategy literature. The measures for the information distribution, learning values, symbolic information use, and memory were sourced from Hughes and Morgan (2008), Morgan and Turnell (2003), Diamantopoulos and Souchon (1999), and Hult et al. (2002), respectively. These measures capture the characteristics of knowledge management activities revolving around creating, storing, and deploying knowledge as outlined by Grant (1996a). For dynamic strategic planning capability, measures by Bailey et al. (2000) are relied on as these reflect an ability to anticipate and respond to the market environment to direct and reconfigure resources through routines that are learned, highly patterned, quasi-repetitious and largely based on tacit knowledge (e.g., Slotegraaf and Dickson, 2004). Several factors are controlled for. Flexibility is created when the organization has a diverse portfolio of strategic options to employ and reflects the capacity to alter strategy, and as such, was controlled for. Centralization is controlled for as due to the rigidity hypothesis associated with planning processes (limiting the application of knowledge).

The CFA Model includes all knowledge application constructs, planning capability, and control variables. The model reveals acceptable fit: $\chi^{2}$ (d.f.) $=610.38(356) ; \chi^{2} /$ d.f. $=1.71$; $\mathrm{RMSEA}=.07 ; \mathrm{CFI}=.95 ; \mathrm{NNFI}=.94 ; \mathrm{IFI}=.95 ;$ Standardized $\mathrm{RMR}=.09 . \mathrm{CFA}$ results and all measurement item properties are presented in Appendix A. All $t$-values load significantly on the 
specified construct indicating convergent validity. Composite reliability (CR) and average variance extracted (AVE) are presented in Table 1. All CR values are above acceptable minimum thresholds exceeding .50 (Bagozzi and Yi, 1988), implying both convergent validity and model reliability. To ensure the AVE values are acceptable, the square root of AVE for each construct is shown on the diagonal of the correlation matrix. These values exceed the correlations and demonstrate discriminant validity (Kyriakopoulos et al., 2016).

\section{...Insert Table 1 Here...}

\section{Common Method Variance (CMV)}

A single source self-report instrument is used for generating most of the data and so, CMV may underlie the data. This bias was proactively addressed in developing the questionnaire by placing measurement scales in random order; not implying any idealized responses; minimizing questionnaire length; and providing detailed instructions for respondents. CMV is examined via a marker variable test (Lindell and Whitney, 2001), but examining for difference in covariance rather than correlation (Kyriakopoulos et al., 2016) as (1) correlation has no effect on analysis in LISREL using maximum likelihood estimation, and (2) CMV affects variance and it is this that requires examination and not correlation. Respondent knowledge is chosen as the theoretically unrelated marker and this is not correlated to any of the variables in the model. Following Lindell and Whitney's (2001) guidance a CMV-adjusted covariance matrix is calculated and is used in the CFA to compute a CMV-adjusted CFA. There are no significant differences between the model fit statistics for the original CFA and the CMV-adjusted CFA. Common method variance, then, does not appear to be a threat in the data. 


\section{Analysis and Results}

Structural equation modeling is done with LISREL 8.80 using maximum likelihood estimation. Table 2 presents the results. The results for each hypothesis are reported in turn.

Hypothesis 1 expected strategic planning capability to be positively influenced by information distribution. The results $(\gamma=.21, p<.10)$ confirm hypothesis 1 . Hypothesis 2 proposed that strategic planning capability would also be positively influenced by learning values. The hypothesized effect of learning values is unsupported $(\gamma=-.08, n s)$ however. Hypothesis 3 posited that a strategic planning capability will be negatively influenced by symbolic information use. As predicted, symbolic information use negatively affects strategic planning capability development $(\gamma=-.15, p<.05)$, providing support for hypothesis 3 . Finally, hypothesis 4 expected strategic planning capability development to be positively influenced by memory. Organizational memory $(\gamma=.30, p<.01)$ positively influences the development of a strategic planning capability, supporting hypothesis 4 .

\section{...Insert Table 2 Here...}

\section{Discussion}

A primary tenet of the KBT is that knowledge is central for the development of capabilities (Grant, 1996a, 1996b). This research supports this aspect of the theory in high technology organizations, demonstrating that information dissemination and organizational memory are positively related to the development of a strategic planning capability. This in turn addresses the lack of wider theory integration that typifies planning research (e.g., Wolf and Floyd, 2017) by offering distinct knowledge management antecedents to this discussion (e.g., Dameron et al., 2015). The roles of information dissemination and memory contribute to a more coherent 
understanding of how strategy materializes among firms in unpredictable environments (Thomas and Ambrosini, 2015). Providing empirical evidence of the positive role of information distribution and memory therein extends the relevance of these two dimensions beyond their observed positive effect on new product development capability (Marsh and Stock, 2006), to a dynamic strategic planning capability. However, not all knowledge management activities are appropriate for the development of a strategic planning capability.

While theoretically, the KBT indicates that activities that apply and integrate knowledge are critical to capability development, no support is found for a relationship between learning values and strategic planning capability. One explanation for the non-significant finding of learning values is offered by Chia and Holt (2009). They suggest that in process-based strategizing, such as under planning, emphasis is placed on addressing contingencies as they arise rather than what exists. This more reactive interpretation of planning thus minimizes the need to learn about what is occurring in the environment in a broader sense, in favor of addressing more defined environmental issues. Much of the knowledge management literature emphasizes the salience of learning in strategizing and clearly it is necessary to revisit its role in developing a strategic planning capability.

The results regarding symbolic information use demand that planning theory capture the process by which some managers manipulate or misuse current information when planning. Clearly, some managers may seek to further their own agenda by manipulating information collected previously or which is in the process of being interpreted, whether this is always a conscious act or a consequence of subconscious behavior is not clear, however. Nevertheless, there are clear dangers in this for the appropriateness of strategic planning. As Vyas and Souchon (2003) note, firms must guard against using information in a symbolic manner in favor of the 
objective use of information and this is observed to be paramount to the successful development of a strategic planning capability. The need to have multiple executives analyze and interpret information is clearly of priority consistent with the move towards diverse strategy teams in contemporary planning (Whittington et al., 2016). How firms can mitigate symbolic information use in their strategy process, therefore, remains a research priority given the lack of investigation of its role in firm strategizing and what people actually do in the strategy process (e.g., MacLean and MacIntosh, 2015).

\section{Planning: Dispelling the Practitioner Bias}

Much of the criticism directed at strategic planning to date concerns the poor application of planning, rather than problems with planning itself. For instance, evidence of planning tools being used persistently independent of context suggests that their use is more dependent on standardized, organizational practices than on the fit of the tool with the situation in the environment (Jarzabkoski and Kaplan, 2015). Moreover, strategic plans are often developed on an annual basis, regardless of the actual pace of change in the environment (Reeves et al., 2012). A consequence of a lack of knowledge dissemination and failings in organizational memory. Hence, the perception of strategic planning in practice has become one of affordability, consisting of whichever initiatives fit the company's resources (Martin, 2014); rather than as a means for real-time information collection and interpretation and adaptation to new information (Thomas and Ambrosini, 2015). One explanation for the reliance on traditional 'static' strategic planning may be attributed to a lack of recent research compared to the body of research from prior decades when environmental stability was common (Whittington et al., 2016). 
Nevertheless, adherence to traditional planning that employs a stable core of norms, expectations and routines (Thomas and Ambrosini, 2015) will likely lead to reduced adaptability under conditions of uncertainty. Yet, when a strategic planning capability is informed and developed by information dissemination and organizational memory, planning activity will fit the situational context of the firm. For instance, under turbulent conditions plans should take the form of 'rough hypotheses based on the best available data...to best capture change signals and minimize information loss and time lags' (Reeves et al., 2012, p. 5). The planning routines and values of search, analysis, and assessment (Bailey et al., 2000) should, then, be appropriately supported by investments in knowledge dissemination and memory on a continual basis. Increasing managerial participation in contemporary strategic planning, via the inputs of wider organizational members and their knowledge (Whittington et al., 2016), can ensure that information dissemination and memory are effectively cultivated for a dynamic strategic planning capability.

Though symbolic information use was identified as a damaging activity for the development of a strategic planning capability, managers need to appreciate that this is distinct from organizational memory. The former encompasses the collection of information that is to be used out-of-context and manipulated to suit the agenda of the person using the information. In contrast, organizational memory is based on information and knowledge gathered in the past that has been retained in the form of knowledge stocks. Past information that has been retained for future use is less vulnerable to the effect of symbolic information use, largely owing to the fact that these knowledge stocks are typically understood across the organization and are, therefore, less vulnerable to misuse by individuals. 


\section{Limitations and Future Research}

This study was not without its limitations. First, a cross-sectional design is adopted and whilst this approach is consistent with existing planning research it was not possible to observe the effects over time. Second, using a single informant approach to generate data can be problematic. Although no common method problems were found, and key informants were well qualified to provide data, adopting a multiple informant approach is desirable. Third, the results should not be generalized to populations that markedly differ from the high technology firms sampled.

Several avenues for future research are noted. First, managers may conduct environmental scanning not to develop appropriate planning for future success, but to commit the firm to its existing strategy. This may occur as a result of symbolic information use, thus, the role of symbolic information use warrants particular attention in future strategic planning research. Second, and linked to the former, there are grounds to suggest that symbolic information use may also have a negative effect on performance directly or moderates the strategic planning capability-performance relationship. Strategic management based on poor or misused information may have a detrimental effect on the ability to achieve strategic goals and, therefore, superior performance becomes untenable. This should be examined in future studies. Third, strategic planning may create rigidity when managers fail to respond to given environmental conditions (Atuahene-Gima, 2005) particularly in the face of an exogenous shock (Newey and Zahra, 2009) and existential crisis that threatens continuity (Sarkar and Osiyevskyy, 2017). Future research must study situations in which rigidity from planning can arise and the reasons for this. Fourth, scholars should develop a holistic model of the antecedents to strategic planning. This is a significant gap currently in the literature with many models considering the antecedent issue from singular perspectives. A more comprehensive approach here would go a long way to 
generating a complete understanding of the drivers of effective strategic planning, their interaction, and how the development of strategic planning capabilities occur such that scholars and managers understand how firms can succeed at strategic planning. Fifth, scholars have suggested that planning could itself have an informational role (Mintzberg, 1994) and may provide a mechanism to encourage learning (Brews and Hunt, 1999). For instance, in planning extensively, managers are likely to develop new insights and create better understanding of strategy and their environment. Indeed, Menon et al. (1999) suggest that thoroughness in planning can enhance learning through the development of complex and richer mental maps, although no support was found in their results for such a hypothesis. Future research should delineate the role of different learning dimensions, as outlined by Huber (1991), on both the origins and outcomes of strategic planning; and examine whether these outcomes form an essential feedback loop to knowledge distribution and memory.

\section{Conclusion}

Drawing on the KBT, this study sought to address an important strategic dilemma for managers: how can organizations develop a strategic planning capability? A strategic planning capability represents the organization's core routines and skills in carrying out the activity of planning (e.g., Day, 1994). The capability endows firms with the ability to anticipate and respond to changes in the market environment through continual reconfiguration of the resource base, ensuring convergence with a changeable business environment (e.g., Teece, 2014). The strategic planning capability is fostered by the knowledge management activities of information distribution and organizational memory. Though counterintuitive, learning values is insignificant in the pursuit of strategic planning capability development. Symbolic information use is shown to degrade the 
development of a strategic planning capability and managers must be conscious of how knowledge might be being misused by colleagues to further personal gain at the disadvantage of planning effectiveness. Collectively, the findings provide new empirical evidence as to the role of knowledge management activities for the development of a strategic planning capability, which has thus far been lacking in planning theory due to a neglect of its origins.

\section{References}

Atuahene-Gima, K. (2005), "Resolving the capability-rigidity paradox in new product innovation”, Journal of Marketing, Vol. 69 No. 4, pp. 61-83.

Atuahene-Gima, K. and Li, H. (2004), "Strategic decision comprehensiveness and new product development outcomes in new technology ventures", Academy of Management Journal, Vol. 47 No. 4 , pp. 583-597.

Atuahene-Gima, K. and Murray, J.Y. (2004), “Antecedents and outcomes of marketing strategy comprehensiveness", Journal of Marketing, Vol. 68 No. 4, pp. 33-46.

Bailey, A., Johnson, G. and Daniels, K. (2000), "Validation of a multi-dimensional measure of strategy development processes”, British Journal of Management, Vol. 11 No. 2, pp. 151-162.

Bagozzi, R.P. and Yi, Y. (1988), "On the evaluation of structural equation models", Journal of the Academy of Marketing Science, Vol. 16 No. 1, pp. 74-94.

Baker, W.E. and Sinkula, J.M. (1999), "The synergistic effect of market orientation and learning orientation on organizational performance", Journal of the Academy of Marketing Science, Vol. 27 No. 4, pp. 411-427. 
Brews, P.J. and Hunt, M.R. (1999), "Learning to plan and planning to learn: resolving the planning school/learning school debate”, Strategic Management Journal, Vol. 20 No. 1, pp. 889-913.

Casey, A.J. and Olivera, F. (2011), "Reflections on organizational memory and forgetting”, Journal of Management Inquiry, Vol. 20 No. 3, pp. 305-310.

Chia, R. and Holt, R. (2009), Strategy without Design, Cambridge University Press, Cambridge. Crick, D. and Crick, J. (2014), “The internationalization strategies of rapidly internationalizing high-tech UK SMEs: Planned and unplanned activities”, European Business Review, Vol. 26 No. 5, pp. 421-448.

Day, G.S. (1994), “The capabilities of market-driven organizations”, Journal of Marketing, Vol. 58 No. 4, pp. 37-52.

Dameron, S., Lê, J.K. and LeBaron, C. (2015), "Materializing strategy and strategizing material: Why matter matters”, British Journal of Management, Vol. 26 No. S1, pp. S1-S12.

Diamantopoulos, A. and Souchon, A.L. (1999), “Measuring export information use: scale development and validation", Journal of Business Research, Vol. 46 No. 1, pp. 1-14.

Dimitriades, Z.S. (2005), “Creating strategic capabilities: Organizational learning and knowledge management in the new economy”, European Business Review, Vol. 17 No. 4, pp. 314-324.

Fredrickson, J.W. (1984), “The comprehensiveness of strategic decision processes: Extension, observations, future directions", Academy of Management Journal, Vol. 27 No. 3, pp. 445466.

Friesl, M. (2012), “Knowledge acquisition strategies and company performance in young high technology companies”, British Journal of Management, Vol. 23 No. 3, pp. 325-343. 
Grant, R.M. (1996a), “Toward a knowledge-based theory of the firm”, Strategic Management Journal, Vol. 17 No. S2, pp. 109-122.

Grant, R.M. (1996b), "Prospering in dynamically-competitive environments: Organizational capability as knowledge integration”, Organization Science, Vol. 7 No. 4, pp. 375-387.

Grant, R.M. (2003), "Strategic planning in a turbulent environment: Evidence from the oil majors", Strategic Management Journal, Vol. 24 No. 6, pp. 491-517.

Hart, S. and Banbury, C. (1994), "How strategy-making processes can make a difference”, Strategic Management Journal, Vol. 15 No. 4, pp. 251-269.

Huber, G.P. (1991), “Organizational learning: The contributing processes and the literatures”, Organization Science, Vol. 2 No. 1, pp. 88-115.

Hughes, P. and Morgan, R.E. (2007), “A resource-advantage perspective of product-market strategy performance \& strategic capital in high technology firms", Industrial Marketing Management, Vol. 36 No. 4, pp. 503-517.

Hughes, P. and Morgan, R.E. (2008), "Fitting strategic resources with product-market strategy: Performance implications", Journal of Business Research, Vol. 61 No. 4, pp. 323-331. Hughes, P. Hodgkinson, I.R., Arshad, D., Hughes, M. and Leone, V. (2018), "Planning to improvise? The role of reasoning in the strategy process: Evidence from Malaysia”, Asia Pacific Journal of Management, Vol. 35 No. 2, pp.449-470.

Hughes, P., Hughes, M. and Morgan, R.E. (2010), "Why do product-market strategies fail? A sociostructural examination under conditions of adherence", Group \& Organization Management, Vol. 35 No. 5, pp. 606-635.

Hughes, P., Souchon, A.L., Nemkova, E., Hodgkinson, I.R., Oliveira, J.S., Boso, N., Hultman, M., Yeboah-Banin, A.A. and Sy-Changco, J. (2019), "Quadratic effects of dynamic decision- 
making capability on innovation orientation and performance: Evidence from Chinese exporters", Industrial Marketing Management, in press.

Hult, G.T.M., Ferrell, O.C. and Hurley, R.F. (2002), “Global organizational learning effects on cycle time performance”, Journal of Business Research, Vol. 55 No. 5, pp. 377-387.

Hunt, S.D. (2000), A General Theory of Competition, Sage, Thousand Oaks, CA.

Hunt, S.D. and Morgan, R.M. (1995), "The comparative advantage theory of competition", Journal of Marketing, Vol. 59 No. 2, pp. 1-15.

Jarzabkowski, P. and Kaplan, S. (2015), "Strategy tools-in-use: A framework for understanding "technologies of rationality" in practice", Strategic Management Journal, Vol. 36 No. 4, pp. 537-558.

Kyriakopoulos, K., Hughes, M. and Hughes, P. (2016), "The role of marketing resources in radical innovation activity: antecedents and payoffs", Journal of Product Innovation Management, Vol. 33 No. 4, pp. 398-417.

Lindell, M.K. and Whitney, D.J. (2001), “Accounting for common method variance in crosssectional designs", Journal of Applied Psychology, Vol. 86 No. 1, pp. 114-121.

MacLean, D. and MacIntosh, R. (2015), "Planning reconsidered: Paradox, poetry and people at the edge of strategy", European Management Journal, Vol. 33 No. 2, pp. $72-78$.

Marsh, S.J. and Stock, G.N. (2006), "Creating dynamic capability: The role of intertemporal integration, knowledge retention, and interpretation", Journal of Product Innovation Management, Vol. 23 No. 5, pp. 422-436.

Martin, R.L. (2014), “The big lie of strategic planning”, Harvard Business Review, Vol. 92 No. 1/2, pp. 3-8. 
Menon, A. and Varadarajan, P.R. (1992), “A model of marketing knowledge use within firms", Journal of Marketing, Vol. 56 No. 4, pp. 53-71.

Menon, A., Bharadwaj, S.G., Adidam, P.T. and Edison, S.W. (1999), “Antecedents and consequences of marketing strategy making: A model and a test”, Journal of Marketing, Vol. 63 No. 2, pp. 18-40.

Mintzberg, H. (1994), “The fall and rise of strategic planning”, Harvard Business Review, Vol. 72 No. 1, pp. 107-114.

Morgan, R.E. and Turnell, C.R. (2003), "Market-based organizational learning and market performance gains", British Journal of Management, Vol. 14 No. 3, pp. 255-274.

Nahapiet, J. and Ghoshal, S. (1998), "Social capital, intellectual capital, and the organizational advantage", Academy of Management Review, Vol. 23 No. 2, pp. 242-266.

Reeves, M., Love, C. and Tillmanns, P. (2012), "Your strategy needs a strategy”, Harvard Business Review, Vol. 90 No. 9, pp. 76-83.

Rogers, P.R., Miller, A. and Judge, W.Q. (1999), “Using information-processing theory to understand planning/performance relationships in the context of strategy", Strategic Management Journal, Vol. 20 No. 6, pp. 567-577.

Sarkar, S. and Osiyevskyy, O. (2017), “Organizational change and rigidity during crisis: A review of the paradox", European Management Journal, Vol. 36 No. 1, pp. 47-58.

Sinkula, J.M. (1994), “Market information processing and organizational learning”, Journal of Marketing, Vol. 58 No. 1, pp. 35-45.

Slater, S.F., Olson, E.M. and Hult, G.T.M. (2006), “The moderating role of strategic orientation on the strategy formation capability-performance relationship", Strategic Management Journal, Vol. 27 No. 12, pp. 1221-1231. 
Slater, S.F. and Narver, J.C. (1995), "Market orientation and the learning organization”, Journal of Marketing, Vol. 59 No. 3, pp. 63-74.

Slotegraaf, R.J. and Dickson, P.R. (2004), “The paradox of a marketing strategic planning capability", Journal of the Academy of Marketing Science, Vol. 32 No. 4, pp. 371-385.

Teece, D.J. (2014), “The foundations of enterprise performance: Dynamic and ordinary capabilities in an (economic) theory of firms", Academy of Management Perspectives, Vol. 28 No. 4, pp. 328-352.

Thomas, L. and Ambrosini, V. (2015), "Materializing strategy: The role of comprehensiveness and management controls in strategy formation in volatile environments", British Journal of Management, Vol. 26 No. S1, pp. S105-S124.

Vyas, R. and Souchon, A.L. (2003), "Symbolic use of export information: A multidisciplinary approach to conceptual development and key consequences", International Marketing Review, Vol. 20 No. 1, pp. 67-94.

Walsh, J.P. and Ungson, G.R. (1991), "Organizational memory”, Academy of Management Review, Vol. 16 No. 1, pp. 57-91.

Whittington, R., Cailluet, L. and Yakis-Douglas, B. (2011), "Opening strategy: Evolution of a precarious profession”, British Journal of Management, Vol. 22 No. 3, pp. 531-544.

Whittington, R., Yakis-Douglas, B., Ahn, K. and Cailluet, L. (2016), "Strategic planners in more turbulent times: The changing job characteristics of strategy professionals, 1960-2003", Long Range Planning, Vol. 50 No. 1, pp. 108-119.

Wolf, C. and Floyd, S.W. (2017), "Strategic planning research toward a theory-driven agenda", Journal of Management, Vol. 43 No. 6, pp. 1754-1788. 
Zollo, M. and Winter, S.G. (2002), "Deliberate learning and the evolution of dynamic capabilities", Organization Science, Vol. 13 No. 3, pp. 339-351. 
Table 1. Correlation matrix and descriptive statistics

\begin{tabular}{|c|c|c|c|c|c|c|c|}
\hline & 1 & 2 & 3 & 4 & 5 & 6 & 7 \\
\hline 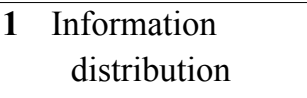 & $.76^{\mathrm{a}}$ & & & & & & \\
\hline 2 Learning values & $.48^{* *}$ & .91 & & & & & \\
\hline $\begin{array}{l}3 \text { Symbolic } \\
\text { information use }\end{array}$ & $-.19 *$ & -.16 & .66 & & & & \\
\hline $\begin{array}{l}\text { Organizational } \\
\text { memory }\end{array}$ & $.55^{* *}$ & $.37 * *$ & $-.25 * *$ & .79 & & & \\
\hline $\begin{array}{l}5 \text { Strategic planning } \\
\text { capability }\end{array}$ & $.44^{* *}$ & $.30^{* *}$ & $-.27 * *$ & $.44^{* *}$ & .80 & & \\
\hline 6 Flexibility & $.35^{* *}$ & $.42 * *$ & -.11 & $-.20 *$ & $.38^{* *}$ & .74 & \\
\hline 7 Centralization & $-.20^{*}$ & $-.20^{*}$ & .10 & -.14 & $-.16^{*}$ & -.15 & .80 \\
\hline CR & .80 & .91 & .80 & .83 & .93 & .83 & .88 \\
\hline AVE & .57 & .83 & .44 & .63 & .64 & .55 & .64 \\
\hline Mean & 4.88 & 4.99 & 3.77 & 3.67 & 4.05 & 4.83 & 4.87 \\
\hline SD & 1.14 & 1.24 & 1.11 & 1.27 & 1.13 & .88 & 1.32 \\
\hline
\end{tabular}

Notes: ${ }^{* *} p<.01{ }^{*} p<.05$; SD: Standard deviation; CR: Composite reliability; AVE: Average variance extracted; ${ }^{\text {a }}$ Figures on the diagonal are square roots of AVE; n/a: Not applicable (single measure latent variable). 
2

3

4

5

6

7

8

9

10

11

12

13

14

15

16

17

18

19

20

21

22

23

24

25

26

27

28

29

30

31

32

33

34

35

36

37

38

39

40

41

42

43

44

45

46

47

48

49

50

51

52

53

54

55

56

57

58

59

60

Table 2. Structural equation modeling results ${ }^{\mathrm{a}}$

\begin{tabular}{|c|c|c|c|}
\hline \multirow[b]{2}{*}{ Knowledge management activities } & \multirow[b]{2}{*}{ Hypotheses } & \multicolumn{2}{|c|}{ Strategic planning capability } \\
\hline & & $\begin{array}{c}\text { Standardized path } \\
\text { estimate }\end{array}$ & $t$-value ${ }^{\mathrm{b}}$ \\
\hline \multicolumn{4}{|l|}{ Direct effects } \\
\hline Information distribution & $\mathrm{H}_{1}^{+}$ & .21 & $1.45 \dagger$ \\
\hline Learning values & $\mathrm{H}_{2}^{+}$ & -.08 & -.81 \\
\hline Symbolic information use & $\mathrm{H}_{3}^{-}$ & -.15 & $-1.78^{*}$ \\
\hline Organizational memory & $\mathrm{H}_{4}^{+}$ & .30 & $2.35^{* *}$ \\
\hline \multicolumn{4}{|l|}{ Controls } \\
\hline Flexibility & & .31 & $3.12 * *$ \\
\hline Centralization & & -.02 & -.24 \\
\hline \multicolumn{4}{|l|}{ Squared Multiple Correlations } \\
\hline For Reduced Form & & & \\
\hline
\end{tabular}

Notes: ${ }^{\mathrm{a}}$ Results from single structural equation model (unrestricted model); ${ }^{\mathrm{b}}$ Critical t-values (one-tailed): when $* * p=.01$, critical t-value $=2.326$; when $* p=.05$, critical t-value $=1.645 ;$ when $\uparrow p=.10$, critical t-value $=1.282$. 
Appendix A. Measurement item properties

\begin{tabular}{|c|c|c|c|}
\hline Construct $^{\mathrm{a}}$ & Measurement item & $\begin{array}{c}\text { Standardized } \\
\text { factor } \\
\text { loading }\end{array}$ & $t$-value \\
\hline $\begin{array}{c}\text { Information } \\
\text { distribution }\end{array}$ & $\begin{array}{l}\text { Meetings are frequently conducted to identify what can be learned and } \\
\text { subsequently improved upon from activities and events } \\
\text { Lessons learned from past product-market decisions are thoroughly } \\
\text { shared and discussed with others in the organization } \\
\text { Exchange of information and experiences takes place frequently and } \\
\text { informally among product-market strategic decision-makers }\end{array}$ & .81 & 9.18 \\
\hline Learning values & $\begin{array}{l}\text { The sense around this organization is that employee learning is an } \\
\text { investment not an expense } \\
\text { The basic values of this organization include learning as a key to } \\
\text { improvement }\end{array}$ & .99 & 10.16 \\
\hline $\begin{array}{l}\text { Organizational } \\
\text { memory }\end{array}$ & $\begin{array}{l}\text { We always audit unsuccessful product-market strategy endeavors and } \\
\text { communicate the lessons learned } \\
\text { We have specific mechanisms for sharing lessons learned in the product- } \\
\text { market strategy process } \\
\text { Formal routines exist to uncover faulty assumptions about the product- } \\
\text { market strategy process }\end{array}$ & .84 & 8.15 \\
\hline $\begin{array}{l}\text { Symbolic } \\
\text { information } \\
\text { use }\end{array}$ & $\begin{array}{l}\text { Information is often collected to justify a strategic product-market } \\
\text { decision already made } \\
\text { Information is used to justify strategic product-market decisions is often } \\
\text { collected/interpreted after the decision has been made } \\
\text { Information is often used to reinforce expectations } \\
\text { Information is sometimes manipulated in order to justify decisions really } \\
\text { made on the basis of instinct } \\
\text { Key executives often 'distort' information in passing it on }\end{array}$ & $\begin{array}{l}.57 \\
.63\end{array}$ & $\begin{array}{l}5.76 \\
6.27\end{array}$ \\
\hline $\begin{array}{l}\text { Strategic } \\
\text { planning } \\
\text { capability }\end{array}$ & $\begin{array}{l}\text { Our product-market strategy is made explicit in the form of precise plans } \\
\text { When we formulate a product-market strategy it is planned in detail } \\
\text { We have precise procedures for achieving strategic product-market } \\
\text { objectives } \\
\text { We have well-defined planning procedures to search for solutions to } \\
\text { strategic product-market problems } \\
\text { We meticulously assess many alternatives when deciding on a product- } \\
\text { market strategy } \\
\text { We evaluate potential strategic product-market options against explicit } \\
\text { strategic product-market objectives } \\
\text { We have definite and precise strategic product-market objectives } \\
\text { We make strategic product-market decisions based on a systematic } \\
\text { analysis of our business environment }\end{array}$ & $\begin{array}{l}.77 \\
.86\end{array}$ & $\begin{array}{r}10.04 \\
10.79 \\
10.87 \\
9.56\end{array}$ \\
\hline Flexibility & $\begin{array}{l}\text { Adapting your product-market strategy adequately to changes in the } \\
\text { business environment of your organization? } \\
\text { Adapting your product-market strategy adequately to changes in } \\
\text { competitors' product-market strategies? } \\
\text { Adapting your product-market strategy quickly to the changing needs of }\end{array}$ & $\begin{array}{l}.70 \\
.78\end{array}$ & $\begin{array}{l}7.00 \\
7.53\end{array}$ \\
\hline
\end{tabular}


customers?

Reacting quickly to new product-market threats?

Centralization There can be little action taken in the organization until a superior makes a decision

A person who wants to make his or her own decisions would be quickly discouraged in the organization

Even small matters have to be referred to someone with more authority for a final decision

Any decision a person in the organization makes has to have his or her boss's approval (r)

Notes: aAll items anchored by 7-point agreement scales ( 1 = "Strongly disagree" to 7 = "Strongly agree") with the exception of

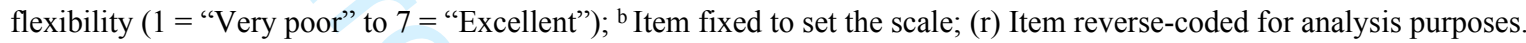

